\title{
Аркадий Ковельман
}

(Московский государственный университет им. М. В. Ломоносова, Москва, Россия)

Доктор исторических наук, профессор, заведующий кафедрой иудаики ИСАА

МГУ имени М. В. Ломоносова

E-mail: arkady.kovelman@gmail.com

ID ORCID: 0000-0001-7648-154X

\section{Российская иудаика вчера и завтра}

\begin{abstract}
Аннотация: Академическая иудаика в постсоветской России не является продолжением того скромного начала, которое состоялось до революции 1917. Она зародилась в период Застоя как любительское национально-интеллектуальное движение. Крушение СССР легализовало иудаику, но обрушило культурный энтузиазм интеллигенции, да и саму интеллигенцию. К счастью, российские исследователи получили щедрую поддержку от израильских и американских университетов и от благотворительных фондов. Но креативность российской иудаики все еще находится в спящем состоянии. Чтобы доказать право на существование, наука должна производить больше качественных книг и статей. Новый журнал может помочь в решении этой проблемы.
\end{abstract}

Ключевые слова: Иудаика, русско-еврейские интеллектуалы, застой в СССР

DOI: 10.31168/2658-3364.2018.1.1.2

Новая российская иудаика родилась в конце восьмидесятых годов и проделала путь от идейного движения к университетской науке. Конечно, движение не может «проделать путь», оно совершается вдоль какого-то пути. Конец пути есть прекращение движения, тепловая смерть, обретение «статуса» (в данном случае - статуса университетской науки). Но попытка избежать статуса есть отказ от взросления, вечное младенчество. Лучше уж умереть от старости, чем вечно подавать надежды. Те или иные отрасли науки действительно умирают и ведут призрачное посмертное существование, хотя способны при благоприятных обстоятельствах ожить вновь.

Скажем прямо: величие старой российской иудаики сильно преувеличено (хотя отрицать отдельные блестящие достижения невозможно). Об этой науке сказано Мандельштамом в «Шуме времени» в главе «Книжный шкап»: «Русская история евреев, написанная неуклюжим и робким языком говорящего по-русски талмудиста» [Мандельштам 2001, 309]. Возможно, русской иудаике предстояло блестящее будущее, о чем свидетельствуют разбежавшиеся по свету или оставшиеся в СССР для показательной порки студенты той эпохи: Элиас (Илья Иосифович) Бикерман, Авигдор (Виктор) 
Чериковер, Соломон Яковлевич Лурье, Бенцион Динур (Динабург), Ольга Михайловна Фрейденберг ${ }^{1}$ и другие. Они учились у великих учителей (М.И. Ростовцева, С.А. Жебелева, Ф.Ф. Зелинского) и были готовы конвертировать просветительское движение в академический статус. Но получилась еще одна диаспора - академическая. Те, кто остался в СССР, попросту забросили еврейские темы.

Новая российская иудаика с той старой почти не связана генетически. У ее истоков стояли два исторических феномена. Во-первых, это были небольшие кружки эпохи застоя и перестройки - «Еврейская историко-этнографическая комиссия» и «Еврейское историческое общество». Во-вторых, это был весь гуманитарно-интеллектуальный пейзаж семидесятых-восьмидесятых годов. Пейзаж не был статичным и по сути представлял собой движение недовольных режимом интеллектуалов. Евреи невиданным процентом входили в число лидеров этого движения: Ю.М. Лотман, А.Я. Гуревич, Н.Я. Эйдельман и др. В качестве евреев они в своем творчестве старательно чурались еврейской тематики ${ }^{2}$. Казалось бы, при изучении культурных кодов русской и европейской культуры почти невозможно миновать Библию, но они умудрялись. Были исследователи (И.Д. Амусин, И.Ш. Шифман, Й.П. Вейнберг и др.), сумевшие отгородить участок для библеистики и еврейской истории в пределах истории древности и семитологии. Но для последующего развития важным казалось не изучение еврейской истории как таковое, а фанатизм культуры.

Тем, кто дожил до крушения режима, казалось, что все теперь только начинается, а на самом деле все кончалось. Возникали научные институты и даже гуманитарные университеты, вбиравшие в себя элиту застойных годов - от С.С. Аверинцева и Вяч.Вс. Иванова до А.Я. Гуревича и Г. С. Кнабе. Элита очень скоро ушла в иные страны или в мир иной, не оставив достойных наследников. В этом не было ничего трагического. Именно тогда Ю.М. Лотман писал о периодах «спада» как о паузе в диалоге культур, заполненной «интенсивным получением информации» [Лотман 1996, 195]. И действительно, наступило время перевода. Книги доставались из спецхранов и переводились с французского, немецкого, английского. Переиздание старых (прежде запретных или «отложенных») книг было разновидностью перевода - через эпоху.

Ровно в этой ситуации новая российская иудаика возникла как чертик из табакерки. Пока еврейская народная масса исчезала в пространствах

\footnotetext{
${ }^{1}$ Включая О.М. Фрейденберг в этот список, я имею в виду ее раннюю работу «Въезд в Иерусалим на осле» (1922). См. [Фрейденберг 1978, 491-531]. У С.Я. Лурье важна его ранняя (1922) работа «Антисемитизм в древнем мире» [Лурье 2009], а также статьи в журнале «Еврейская старина» и в сборнике «Еврейская мысль» [Лурье 1926]. ${ }^{2}$ Я не беру здесь мемуары Гуревича [Гуревич 2004] и в особенности публицистику Эйдельмана (его переписку с Астафьевым), где еврейская тема звучит горько и больно [Эйдельман - Астафьев 1990].
} 
Америки, Австралии, Германии или «делала жизнь» в Израиле, застрявшие в СССР интеллигенты пытались осуществить идеалы то ли еврейского «культурнического движения», то ли гуманитарного расцвета эпохи застоя. В этом предприятии участвовали не только евреи, но и русские, и украинцы, и белорусы, и литовцы, и латыши, для которых еврейская тематика была в центре идейного интереса (религиозного или национального). Если не считать тех немногих, кто уже в эпоху застоя сумел укорениться в гетто семитологии и древней истории, все это были не специалисты, а часто даже и не гуманитарии. Освоение ими новой специальности сопровождалось массивным импортом. Из-за рубежей новой России импортировались израильские и американские ученые, несущие слово истины. Возникли университетские программы, основанные на привозном преподавании. Импорт сопровождался экспортом - выпускники программ уезжали на Юг и на Запад, в страны-поставщики иудаики. Кое-кто оставался. Закончился ли этот период? Наступила ли фаза «трансляции» по терминологии Лотмана? Можно ли говорить, что насыщение текстами уже «достигает определенного порога», что «приводятся в движение внутренние механизмы текстопорождения принимающей структуры» [Лотман 1996, 195]? Новый журнал может стать пробным камнем для проверки этой гипотезы.

\section{Литература и источники}

Гуревич 2004 - Гуревич А.Я. История историка. М.: Российская политическая энциклопедия (РОССПЭН), 2004.

Лотман 1996 - Лотман Ю.М. Внутри мыслящих миров. Человек - текст семиосфера - история. М., 1996.

Лурье 1926 - Лурье С.Я. Библейский рассказ о пребывании евреев в Египте // Еврейская мысль. 1926. Т. II. С. 81-129.

Лурье 2009 - Лурье С.Я. Антисемитизм в древнем мире. Попытки объяснения его в науке и его причины / Подгот. текста, предисл., коммент. И.А. Левинской. М.; Иерусалим: Мосты культуры / Гешарим, 2009.

Мандельштам 2001 - Мандельштам О. Стихотворения. Проза. М., 2001. Фрейденберг 1978 - Фрейденберг О.М. Миф и литература древности / Сост., подгот. текста, коммент. и послесл. Н.В. Брагинской. М.: Главная редакция восточной литературы издательства «Наука», 1978.

Эйдельман - Астафьев 1990 - Из переписки Н.Я. Эйдельмана и В.П. Астафьева // Даугава. 1990. № 6. С. 62-67. 


\title{
Jewish Studies in Russia: Yesterday and Tomorrow
}

\author{
Arkady Kovelman (Lomonosov Moscow State University, Moscow, Russia) Professor, \\ Head of the Department for Jewish Studies at the Institute of Asian and African Studies, \\ Lomonosov Moscow State University \\ E-mail: arkady.kovelman@gmail.com \\ ID ORCID: 0000-0001-7648-154X
}

\begin{abstract}
There was no continuity between Jewish studies in post-Soviet Russia and the pre-revolutionary period. Rather, interest in Jewish culture and history fermented during the late-Soviet "stagnation" period as a kind of amateur, nationalist-motivated intellectual enterprise. The collapse of the Soviet Union made Jewish studies legal. In the 1990s, however, the cultural enthusiasm of the Russian intelligentsia (as well as the intelligentsia itself) could not be supported by internal resources. Fortunately, at that time Russian scholars received generous support from Israeli and American universities and charity foundations. Yet the creativity of Russian Jewish scholarship has still not realized its potential. There is a need for more rigorous studies to prove its scholarly and intellectual validity, and we hope that the new journal will help to address this need.
\end{abstract}

Keywords: Jewish Studies, Russian Jewish Intelligentsia, Late-Soviet Stagnation

DOI: $10.31168 / 2658-3364.2018 .1 .1 .2$

\section{References}

Freydenberg O.M. Mif i literatura drevnosti / Ed. by N.V. Braginskaya. Moscow, 1978.

Gurevich A.Ya. Istoriia istorika. Moscow, 2004.

Lotman Yu.M. Vnutri mysliashchikh mirov. Chelovek - tekst - semiosfera istoriia. Moscow, 1996.

Lurye S.Ya. Bibleiskii rasskaz o prebyvanii evreev v Egipte // Evreiskaia mysl'. 1926. Vol. II. P. 81-129.

Lurye S.Ya. Antisemitizm v drevnem mire. Popytki ob’iasneniia ego v nauke i ego prichiny / Ed. by I.A. Levinskaya. Moscow; Jerusalem, 2009. 